\title{
Pro-opiomelanocortin processing in the hypothalamus: impact on melanocortin signalling and obesity
}

\author{
L E Pritchard ${ }^{1,2}$, A V Turnbull ${ }^{2}$ and A White ${ }^{1,2}$ \\ ${ }^{1}$ School of Biological Sciences and Faculty of Medicine, Stopford Building, University of Manchester, Manchester M13 9PT, UK \\ ${ }^{2}$ AstraZeneca, Mereside, Alderley Park, Cheshire SK10 4TG, UK \\ (Requests for offprints should be addressed to A White, 3.810 Stopford Building, University of Manchester, Oxford Road, Manchester M13 9PT, UK; \\ Email: awhite@man.ac.uk)
}

\begin{abstract}
Bioactive peptides derived from the prohormone, proopiomelanocortin (POMC), are generated in neurons of the hypothalamus and act as endogenous ligands for the melanocortin-4 receptor (MC4R), a key molecule underlying appetite control and energy homeostasis. It is therefore important to understand many aspects of POMC gene regulation in the brain, as pharmacological manipulation of POMC expression/processing could be a potential strategy to combat obesity. Most studies that have analysed POMC gene expression in the hypothalamus have focused on gene transcription experiments. Ultimately, however, factors that regulate post-translational processing and secretion of peptides will have most bearing on melanocortin signalling. This article focuses on (a) current evidence that
\end{abstract}

POMC is involved in obesity, (b) how POMC transcription is regulated in the hypothalamus, (c) the mechanism by which proteolytic processing of POMC is controlled in the hypothalamus and what peptides are produced and (d) which POMC-derived peptides are the most potent ligands at the melanocortin receptor in vitro and in vivo. It seems that post-translational cleavage of POMC in the hypothalamus may be regulated with respect to energy requirement. We predict that further research into hypothalamic POMC processing, and the proteolytic enzymes involved, may yield important new clues on how flux through the MC4R pathway is regulated.

Journal of Endocrinology (2002) 172, 411-421

\section{Introduction}

It is a common misconception that obesity is simply a consequence of a lack of discipline on the part of affected individuals. On the contrary, it appears that genetic predisposition plays a prominent role in determining whether individuals become obese. Indeed, studies of body mass index (BMI) correlations in monozygotic, dizygotic and biological/adoptive siblings suggest an estimated heritability of obesity of between $50 \%$ and $90 \%$ (Barsh et al. 2000). Although it is a common view that environmental variables, such as the 'western' diet and sedentary lifestyles, have contributed to a marked increase in the prevalence of obesity in the developed world, it is believed that these factors particularly lead to obesity in individuals with a predisposing genetic background (Spiegelman \& Flier 2001). Underlying the genetic basis of obesity is a tightly regulated network of neurochemical pathways within the hypothalamus that physiologically control appetite (reviewed in Schwartz et al. 2000). It is hoped that a detailed understanding of the molecular mechanisms that regulate appetite could ultimately lead to the development of novel therapeutic strategies to suppress food intake. In this regard, the prohormone pro-opiomelanocortin (POMC) is a particularly interesting molecule as there is a great deal of evidence implicating POMC-derived peptides in the homeostatic regulation of appetite and obesity.

\section{Evidence that POMC Plays a Role in Obesity}

\section{Genetic evidence}

Mutations in the POMC gene The identification of rare human obesity syndromes, where single gene mutations cause an obese phenotype that is inherited in a mendelian fashion, have been instrumental in defining the role of several key molecules in appetite control, such as leptin (Montague et al. 1997, Strobel et al. 1998) and the leptin receptor (Clement et al. 1998). Such studies have also implicated a role for POMC in obesity. Two severely obese patients who carry inactivating mutations in the 
POMC gene have been reported. In addition to gross obesity, these patients display adrenal insufficiency and red hair, highlighting the roles of POMC-derived peptides in different tissues (Krude et al. 1998). Recently, three further POMC-deficient individuals have been described (Krude \& Gruters 2000). All the patients are obese and display hyperphagia. The phenotype displayed in POMC null mice is remarkably similar to that observed in human POMC patients. Mice lacking POMC-derived peptides are obese with altered pigmentation and defective adrenal development (Yaswen et al. 1999). These observations in humans and mice demonstrate the involvement of POMC in the biochemical pathways that underlie obesity.

Genome-wide scans for obesity predisposing genes Mendelian obesity disorders caused by mutations in the POMC gene are extremely rare (Hinney et al. 1998). However, there is evidence that POMC also serves as a quantitative trait locus (QTL) in obesity (a genetic factor that interacts with other genes and environmental factors to predispose to complex human phenotypes). Comuzzie et al. (1997) undertook a genome-wide analysis of 458 individuals from 10 extended Mexican American pedigrees, a population particularly predisposed to obesity. This analysis demonstrated that variation in serum leptin levels in these individuals correlated, in part, with genetic variation on chromosome $2 \mathrm{p} 21$ where the POMC gene is located. As serum leptin levels are proportional to body fat deposition, this result suggests that POMC may predispose to obesity in human populations. A frequent problem with genome-wide approaches, which necessitate simultaneous analysis of numerous genetic markers, is that spurious false positive results are obtained as a consequence of multiple testing. Therefore, in order to describe a genetic linkage as significant, stringent statistical thresholds have been set as a guideline for the interpretation of results (Lander \& Kruglyak 1995). Interestingly, in a follow-up study with further genetic markers in the POMC gene region, a LOD score of $7 \cdot 46\left(P=10^{-7}\right)$ was achieved in the same Mexican American families (Hixson et al. 1999). This is an almost unprecedented level of significance for any human QTL so far described, and easily surpasses the statistical threshold required in order to be confident in the validity of the data. It has been demonstrated that the POMC gene maps to the peak of the region of linkage on chromosome $2 \mathrm{p} 21$, although whether it is actually the molecular determinant of the QTL has not yet been categorically demonstrated. Nevertheless, what is particularly interesting about this QTL is that the linkage has been replicated in other studies. Hager et al. (1998) undertook a genome scan in 264 sibpairs of French origin and demonstrated a linkage to serum leptin levels on chromosome $2 \mathrm{p}$. The QTL is also apparent in a population of African Americans (Rotimi et al. 1999). The fact that a major QTL has been identified in several genetically distinct populations, suggests that the biochemical pathways in which this gene is involved may have a wide relevance in energy homeostasis.

\section{Functional evidence}

POMC is expressed in the pituitary gland, skin, immune system and brain (Yeo et al. 2000). Expression in the brain is localised to the arcuate nucleus of the hypothalamus and the nucleus tractus solitarius (NTS) of the caudal medulla (Young et al. 1998). POMC is post-translationally cleaved in a complex way to generate a range of bioactive peptides, including adrenocorticotrophin (ACTH), $\beta$-endorphin and $\alpha_{-}, \beta-$ and $\gamma$-melanocyte stimulating hormones (MSH) (reviewed in Castro \& Morrison 1997) (Fig. 1). The biological effects of POMC-derived peptides are diverse and are largely mediated through melanocortin (MC) receptors of which five have been described. MC1R, MC2R and MC5R have established roles in pigmentation in the skin, adrenal steroidogenesis and thermoregulation respectively (Clark et al. 1993, Robbins et al. 1993, Chen et al. 1997). However, the functional basis of the role of POMC in appetite and obesity is largely due to interactions between POMC-derived peptides in the brain and the neuroendocrine specific receptors, MC3R and MC4R.

MC4R is expressed exclusively within the neuroendocrine system (Mountjoy et al. 1994). It is widely expressed in the brain, but is particularly dense in regions of the hypothalamus that are known to control feeding behaviour, such as the paraventricular nucleus (PVN), dorsomedial hypothalamus (DMH) and the lateral hypothalamic area (LHA) (Mountjoy et al. 1994, Jegou et al. 2000). A number of observations demonstrate that the MC4R has a pivotal role in controlling feeding behaviour. First, MC4R knockout mice demonstrate an obese phenotype, owing to severe hyperphagia (Huszar et al. 1997). This confirms a role for the receptor in appetite regulation. The knockout animals display minimal disturbance of the hypothalamus-pituitary-adrenal axis with no effect on growth, reproduction and thyroid function. This signifies that the role of the MC4R is largely specific to appetite regulation. Secondly, mutations in the MC4R gene in humans have been identified and are associated with an obese phenotype (Vaisse et al. 1998, Yeo et al. 1998). This confirms a role for MC4R in human obesity. In fact, mutations in MC4R are the most common monogenetic form of human obesity described so far (Chiesi et al. 2001). Thirdly, in both mice and humans, heterozygous MC4R mutations display an obese phenotype. This signifies that appetite regulation is sensitive to quantitative variation in MC4R expression. MC4R, therefore, appears to be a key regulatory element of the 'adipostat', the mechanism by which energy stores are held relatively constant (Cone 1999). Fourthly, MC4R-specific agonists have been developed and reduce food intake in rodents without any adverse consequences. MC4R 
antagonists have the opposite effect (Fan et al. 1997, Benoit et al. 2000). Fifthly, in a clinical trial, intranasal daily administration of MC4R ligands decreased body weight in humans (Fehm et al. 2001).

The MC3R also has an important but much less well defined role in energy homeostasis. MC3R knockout mice are obese, but in contrast to MC4R-deficient mice, these animals are not hyperphagic (Butler et al. 2000, Chen et al. 2000). Interestingly, the MC3R, unlike the $\mathrm{MC} 4 \mathrm{R}$, is expressed in POMC neurons of the arcuate nucleus. This suggests that MC3R may mediate a regulatory feedback mechanism in the hypothalamus (Jegou et al. 2000). However, the precise role of MC3R remains ill-defined.

POMC-derived peptides act as natural ligands for both MC3R (Roselli-Rehfuss et al. 1993) and MC4R (Mountjoy et al. 1994). Interactions between POMCderived peptides and MC3R and MC4R are endogenously antagonised by agouti-related peptide (AGRP), a central nervous system-specific homologue of agouti protein (Ollmann et al. 1997). Presumably, the ratio of POMC-derived peptides and AGRP secreted by the hypothalamus control flux through the central melanocortin pathway in a yin-yang fashion. Anatomical evidence for this is supplied by the observation that AGRP and POMC neurons project to identical brain areas (Bagnol et al. 1999). It is therefore important to understand the regulatory mechanisms that are in place to co-ordinate the biosynthesis of these molecules with energy requirement.

\section{Regulation of the POMC Gene in the Hypothalamus}

POMC is clearly an important effector in the regulation of appetite. Many groups have shown that transcription of POMC in the hypothalamus is altered depending on energy requirement in vivo. Acute food deprivation leads to down regulation of POMC in rodents (Brady et al. 1990, Bergendahl et al. 1992, Mizuno et al. 1998). Conversely, POMC expression is upregulated in overfed rats (Hagan et al. 1999). Transcriptional control is at least partially mediated by leptin. POMC mRNA levels are significantly lower in the hypothalami of obese leptin receptor-deficient rats $(f a / f a)$ as compared with lean rats $(+/+,+/ f a)$ (Korner et al. 1999). Similarly, POMC mRNA levels are decreased in leptin deficient $(o b / o b)$ and leptin receptor $(d b / d b)$ deficient mice compared with controls (Mizuno et al. 1998). Moreover, steady-state levels of POMC mRNA in the hypothalamus are increased by leptin treatment (Schwartz et al. 1997). AGRP is also directly regulated by leptin in the arcuate nucleus (Mizuno \& Mobbs 1999). These data imply that peripheral leptin signals are detected and transduced, in part, by POMC and AGRP neurons in the arcuate nucleus of the hypothalamus. This idea is further supported by the fact that both POMC and AGRP neurons coexpress the leptin receptor (Mercer et al. 1996, Cheung et al. 1997). Indeed, a recent report has demonstrated that leptin directly increases action potentials in POMC neurons identified by targeted expression of green fluorescent protein in transgenic mice (Cowley et al. 2001). In addition to the effects of leptin, there is some evidence that plasma insulin levels may have a direct bearing on hypothalamic POMC expression. For example, administration of insulin to rats increases levels of POMC mRNA in the arcuate nucleus (Kim et al. 1999). Plasma glucose levels may also directly affect POMC expression (Mizuno et al. 1999).

The mechanism by which leptin controls POMC expression in the hypothalamus has not been fully elucidated. The leptin receptor signals through the JAK/STAT pathway (Good 2000). It is not clear, however, whether POMC is directly modulated by STAT proteins or indirectly by downstream transcription factors activated by STAT. Nevertheless, it is probable that STAT3 plays a role in regulating hypothalamic POMC expression, as it is expressed within POMC neurons (Hakansson \& Meister 1998). Indeed, direct regulation of POMC by STAT3 has recently been demonstrated in vitro (Bousquet et al. 2000). Recent progress has been made in terms of characterising POMC promoter elements that direct expression in the hypothalamus. Transgenic experiments have shown that 2 kilobases of 5 ' flanking sequence are sufficient to direct pituitary-specific expression of POMC (Rubinstein et al. 1993). However, 13 kilobases of $5^{\prime}$ flanking sequence are required for appropriate spatial and temporal expression in the hypothalamus (Young et al. 1998). This data suggest the existence of specific motifs and transcription factors that co-ordinate hypothalamic POMC expression in response to energy requirement. The identity of these transcription factors is presently unknown.

Glucocorticoids also influence hypothalamic POMC gene expression. In contrast to their inhibitory action in the pituitary gland, it appears that glucocorticoids upregulate POMC gene expression in the hypothalamus. This has been demonstrated in adrenalectomised rats (Wardlaw et al. 1998). Adrenalectomy results in an inhibition of POMC expression and this effect is completely reversed by physiological doses of glucocorticoid replacement. The majority of POMC neurons coexpress glucocorticoid receptors, and glucocorticoid response elements (GRE) have been identified in the POMC promoter. Thus, it is likely that glucocorticoids directly influence POMC expression (Cintra \& Bortolotti 1992, Drouin et al. 1998). It is not known how glucocorticoids elicit different effects on POMC in different tissues, but it is possible interactions with other transcription factors can select for positive or negative regulation from the same GRE (Diamond et al. 1990). 


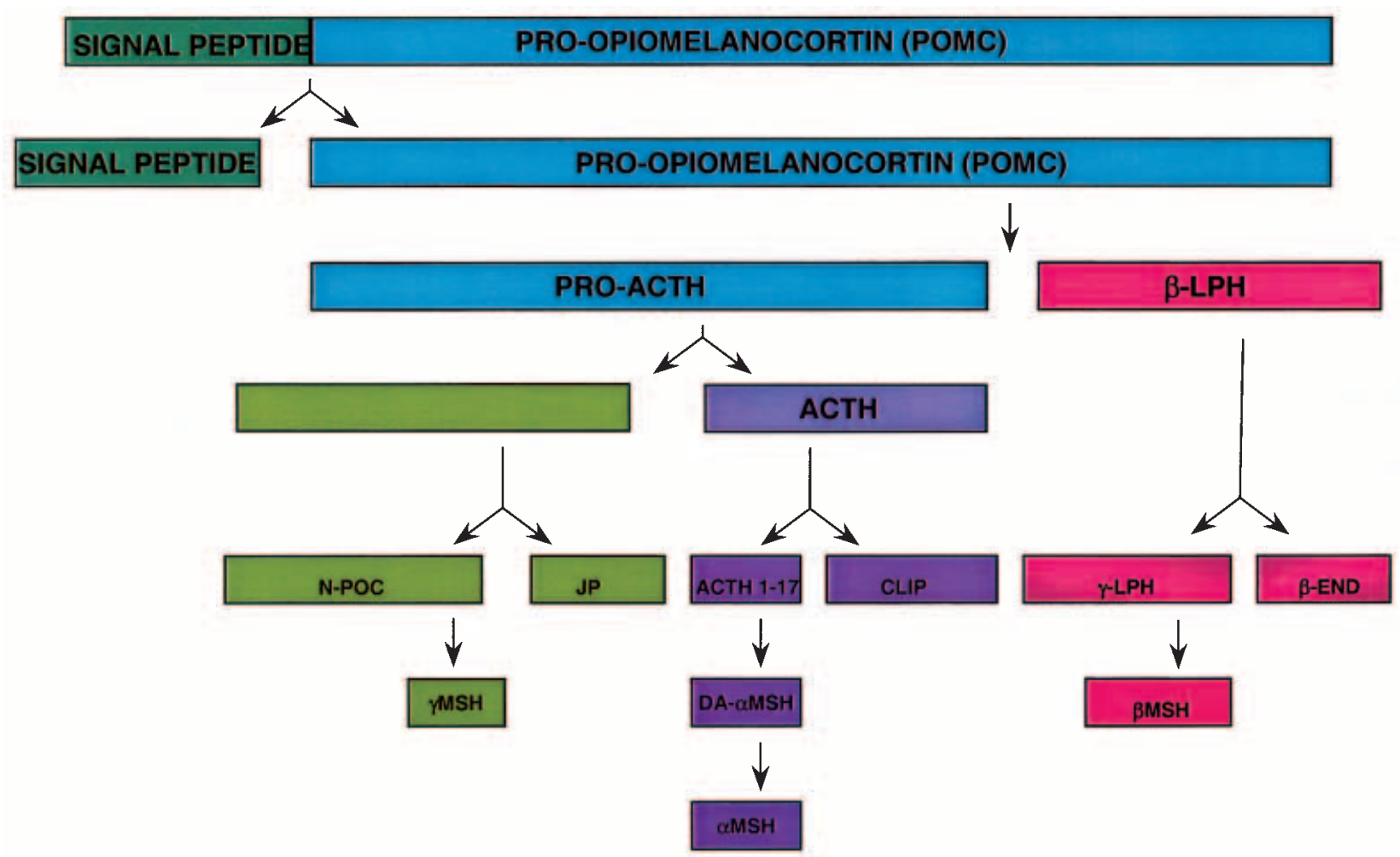

Figure 1 The POMC processing pathway in the hypothalamus. The POMC gene encodes a 32 kilodalton (kDa) precursor that is sorted to the regulated secretory pathway by a signal peptide. The precursor protein contains three main regions: the ACTH sequence that is cleaved in the hypothalamus to ultimately generate $\alpha \mathrm{MSH}$; the C-terminal $\beta$-LPH that is cleaved to generate $\gamma$-LPH, beta endorphin $(\beta$-END) and $\beta \mathrm{MSH}$; and the $\mathrm{N}$-terminal $\gamma \mathrm{MSH}$ containing sequence. The majority of these peptides have been identified in the hypothalamus (see text). However, it is not known whether the relative composition of POMC-derived peptides within the hypothalamus is altered in response to changes in energy requirement.

Other factors, in addition to leptin and glucocorticoids, also influence POMC gene expression. For example, corticotrophin releasing factor $(\mathrm{CRH})$ and leukaemia inhibitory factor (LIF), an interleukin-6-family-related cytokine, synergise to induce POMC expression in murine AtT-20 pituitary cells (Bousquet et al. 1997). $\mathrm{CRH}$ induces POMC expression via the second messengers cyclic adenosine monophosphate (cAMP) and protein kinase A (Boutillier et al. 1998). A number of elements have been identified within the POMC promoter that bind $\mathrm{CRH}$-induced transcription factors (Bousquet et al. 2000). The role of CRH/LIF in controlling hypothalamic POMC gene expression is less certain.

Clearly, transcriptional control of the POMC gene in the hypothalamus is extremely complex and is likely to be influenced by numerous secondary messenger systems. In this way, peripheral signals, including serum leptin, glucocorticoid levels and possibly other factors, converge so that POMC expression is tightly coordinated with energy requirement. The molecular basis of how this occurs, however, is not fully understood.

\section{POMC Processing in the Hypothalamus}

In order to generate mature $\alpha \mathrm{MSH}$, the presumed natural ligand of MC4R, the POMC gene product is subjected to extensive posttranslational modification (Fig. 1). The POMC gene produces a 32 kilodalton $(\mathrm{kDa})$ propeptide. As this precursor peptide is passed through the golgi stacks, it is targeted, via a specific signal peptide, into regulated secretory granules (Cool et al. 1997). POMC is posttranslationally cleaved within these granules by a family of serine proteases, the prohormone convertases (PCs) (Fig. 2). These enzymes cleave prohormones at pairs of dibasic amino acid residues (reviewed in Bergeron et al. 2000). The family members, PC1 and PC2, are of particular importance in the POMC processing cascade (Benjannet et al. 1991, Thomas et al. 1991). However, other processing enzymes may play a role in POMC cleavage. The prohormone convertase PACE4, for example, partially colocalises with POMC in the hypothalamus and has been shown to cleave POMC in vitro (Dong et al. 1995). In addition, an aspartyl protease, 


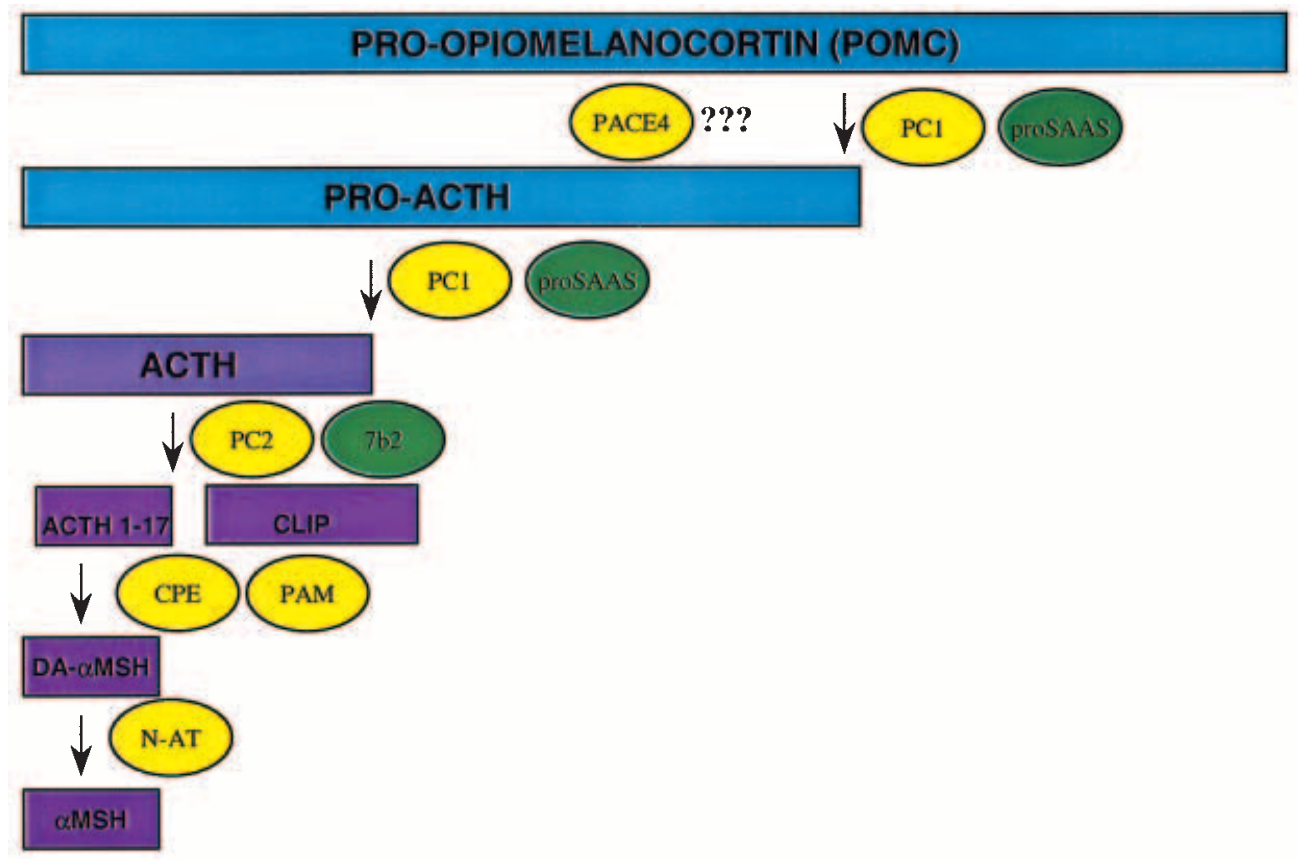

Figure 2 Processing enzymes that are required to generate $\alpha \mathrm{MSH}$ from POMC. PC1 sequentially cleaves POMC to generate proACTH and ACTH. ACTH is subsequently cleaved by PC2 to generate ACTH1-17. Endogenous inhibitors have been identified for both PC1 (proSAAS) and PC2 (7B2). PACE4, a prohormone convertase related to PC1 and PC2, may also play a role in POMC cleavage. Following PC2 cleavage, basic amino acid residues are cleaved from the $\mathrm{C}$ terminal end of $\mathrm{ACTH} 1-17$ by carboxypeptidase $\mathrm{E}$ (CPE). The peptide is subsequently amidated by peptidyl $\alpha$-amidating mono-oxygenase (PAM). Finally, desacetyl $\alpha \mathrm{MSH}$ $(\mathrm{DA}-\alpha \mathrm{MSH})$ is acetylated by $\mathrm{n}$-acetyltransferase $(\mathrm{N}-\mathrm{AT})$, to generate mature $\mathrm{MSH}$.

POMC converting enzyme (PCE), has been purified from secretory vesicles (Loh et al. 1985). This can cleave POMC as well, but the gene encoding PCE has not yet been cloned, precluding any further characterisation of the enzyme.

Analysis of POMC processing in the hypothalamus has been undertaken by (a) pulse chase labelling of POMC products in cultured rat hypothalamic neurons, followed by immunoprecipitation and sephadex gel filtration (Liotta et al. 1980) and (b) fractionation of POMC immunoreactive material from rat (Emerson \& Eipper 1986) and mouse (Allen et al. 2001) hypothalamic extracts by reverse phase high-performance liquid chromatography. These studies, in addition to analysis of POMC processing in the neurointermediate lobe of the pituitary gland (Rouille et al. 1995, and references therein), have led to a basic understanding of the POMC processing pathway in the central nervous system (Figs 1 and 2).

The $32 \mathrm{kDa}$ proprotein is cleaved by PC1 to generate $22 \mathrm{kDa}$ proACTH and $\beta$-lipotrophin $(\beta-\mathrm{LPH})$. ProACTH is further cleaved by PC1 to generate N-POC, joining peptide (JP) and $4.5 \mathrm{kDa}$ ACTH. PC1 is endogenously inhibited by proSAAS, a recently described neuroendocrine specific peptide (Fricker et al. 2000, Qian et al. 2000). PC2 cleaves ACTH to generate ACTH1-17 and corticotrophin-like intermediate lobe peptide (CLIP). PC2 also cleaves $\beta$-LPH to generate $\gamma-\mathrm{LPH}$ and $\beta$-endorphin ( $\beta$-END). In humans, $\gamma$-LPH is cleaved by PC2 to generate $\beta$ MSH (Bertagna et al. 1988). Rats, however, do not have the paired lysine cleavage site required for the formation of $\beta \mathrm{MSH}$. N-POC is cleaved to generate $\gamma \mathrm{MSH}$. PC2 has a specific endogenous inhibitor molecule, called 7B2. This is a multi-functional molecule that is required for appropriate intracellular transport, folding and activation of PC2 (Lindberg et al. 1995). In humans, PC2 is not expressed in the pituitary gland. Therefore, in contrast to the hypothalamus, the main human pituitary-derived products of POMC processing are N-POC, ACTH and $\beta-\mathrm{LPH}$ (White \& Gibson 1998).

In addition to the prohormone convertases and their endogenous inhibitors, other enzymes play a key role in generating mature POMC-derived peptides (Fig. 2). For instance, the generation of mature $\alpha \mathrm{MSH}$ from ACTH1-17 is catalysed by carboxypeptidase E (CPE), peptidyl $\alpha$-amidating mono-oxygenase (PAM) and n-acetyltransferase. First, carboxy-terminal basic amino acids are trimmed from ACTH1-17 by CPE. The peptide is subsequently amidated by PAM to generate desacetyl 
$\alpha \mathrm{MSH}$ (DA- $\alpha \mathrm{MSH})$. This is converted to mature $\alpha \mathrm{MSH}$ by n-acetyltransferase. Both CPE and PAM are believed to have additional functions in peptide processing. CPE seems to play a role in targeting prohormones into secretory granules (Cool et al. 1997). PAM is a bifunctional transmembrane molecule that interacts with components of the actin cytoskeleton and consequently influences trafficking of secretory granules to the cell surface (Ciccotosto et al. 1999).

Therefore, the generation of $\alpha \mathrm{MSH}$ from POMC in the hypothalamus requires a complex pathway of posttranslational modification, involving numerous enzymes.

\section{Regulation of POMC processing in the hypothalamus}

It is possible that post-translational processing of POMC is regulated as a means of ultimately controlling levels of bioactive peptides secreted from POMC neurons in response to alterations in energy requirement. To this end, it is interesting to note that the manipulation of POMC processing molecules in vitro has a profound influence on the relative quantities of POMC peptides produced. For example, overexpression of PC1 in the mouse corticotroph tumour cell line, AtT-20, leads to an increased rate of production of ACTH and $\beta-\mathrm{LPH}$ compared with wildtype cells (Zhou \& Mains 1994). Many other molecules involved in POMC processing influence the extent of peptide biosynthesis. For example, overexpressing proSAAS (Fricker et al. 2000) or PAM (Ciccotosto et al. 1999) in AtT-20 cells inhibits POMC processing. It is not known whether regulation of POMC processing molecules is physiologically important with respect to the rate and extent of POMC processing in the hypothalamus. In this regard, it would be interesting to quantitate expression and functional activity of key processing molecules within POMC neurons in vivo in various rodent models of altered energy homeostasis. Few such studies have been undertaken. However, Renz et al. (2000) have demonstrated that leptin may regulate PC2 expression in vivo. By using a novel gene profiling technology and real-time PCR, they demonstrated that PC2, as well as POMC, is upregulated in the pituitaries of leptin-deficient mice compared with controls. Leptin treatment normalised PC2 expression. Whether PC2, or other processing enzymes, are altered in the hypothalamus was not established in this study. In another study, Berman et al. (2001) found that both PC1 and PC2 levels were differentially altered in the pituitary and brain of $\mathrm{Cpe}^{\mathrm{fat}}$ mice. Other preliminary studies have indicated that biosynthesis and expression of both PC1 and PC2 are stimulated by leptin in vitro (Nillni et al. 2001). These studies infer that leptinmediated satiety status may have a bearing on prohormone processing.

Other studies have shown that prohormone convertases may be regulated with respect to metabolic status. For example, Dong et al. (1997) demonstrated that PC1
mRNA levels in the hypothalamus are increased in adrenalectomised rats compared with controls, suggesting that glucocorticoids regulate PC1 expression. Also both PC1 (Li et al. 2001) and PC2 (Li et al. 2000) are regulated by thyroid hormone.

\section{POMC Processing in the Hypothalamus and Obesity}

The above observations suggest that POMC processing in the brain could be tightly co-ordinated by various metabolic stimuli. It is possible that defects in these phenomena may lead to abnormal energy homeostasis and obesity. Indeed, there are some circumstantial lines of evidence that suggest that defective POMC processing leads to obesity, indicating that differential POMC processing with respect to energy requirement may be physiologically relevant.

(1) A patient has been identified with compound heterozygous mutations in the PC1 gene (O'Rahilly et al. 1995, Jackson et al. 1997). These mutations are predicted to prevent biosynthesis of mature PC1. As a result, prohormone processing in this individual is disrupted and plasma proinsulin and unprocessed POMC levels are elevated. Phenotypic consequences of this defect include extreme childhood obesity, abnormal glucose homeostasis, hypogonadotrophic hypogonadism and hypocortisolism. It is likely that obesity results from a lack of endogenous MC4R ligands in the hypothalamus of this individual.

(2) A second obese patient has been identified with defective POMC processing (Jackson et al. 1999). Plasma POMC levels in the patient were elevated, yet ACTH was undetectable. In contrast to the patient with mutations in PC1, the processing defect appears to be restricted to POMC, as proinsulin and proglucagon processing are normal. The molecular basis of the defect has not been determined, but this data strongly indicates that mechanisms exist by which POMC processing can be specifically modulated without affecting processing of other prohormones. Moreover, this patient clearly indicates that specific disruption of POMC processing is associated with obesity in man.

(3) Certain mouse models of obesity have defective POMC processing. The $C p e^{\text {fat }}$ mouse displays a recessive obesity syndrome associated with high circulating levels of prohormones (Naggert et al. 1995). The defective processing is due to an inactivation of carboxypeptidase $\mathrm{E}$. POMC is missorted to the constitutive pathway in fat/fat mice and is secreted in an unregulated manner (Cool et al. 1997).

The above observations suggest that defective processing of POMC in the central nervous system may disrupt appropriate melanocortin signalling, ultimately resulting in obesity. To investigate this possibility in detail, it would be interesting to undertake a detailed quantitative analysis of 
all POMC products produced in the hypothalamus in response to different states of energy requirement. So far, only a few studies have attempted to quantify POMCderived peptides in the hypothalami of rodent models of obesity. For example, Kim et al. (2000) observed a significant decrease in $\alpha \mathrm{MSH}$ levels in the PVN of obese Zucker rats compared with lean rats. Conversely, Harrold et al. (1999) did not observe any significant change in aMSH levels in whole hypothalamic extracts of dietary obese and food-restricted rats compared with controls. These studies require consolidation and expansion to include analysis of other mature POMC products in the rat hypothalamus. Also, the high molecular weight $\mathrm{MSH}$ precursors, POMC and proACTH, require investigation as our previous analysis has indicated that these molecules exist in significant concentrations in the central nervous system (Tsigos et al. 1993). Quantification of the relative abundance of these precursor molecules to POMCderived peptides in the central nervous system of rodents would indicate whether the POMC processing pathway is regulated to influence melanocortin function.

In an attempt to address these questions, we have recently analysed cerebrospinal fluid (csf) from fed and fasted Wistar rats and lean and obese Zucker rats for POMC-derived peptide content (Pritchard et al. 2001). We have found that analysing POMC immunoreactivity in csf is a convenient and valid means of studying the dynamics of POMC processing in vivo. Having utilised a series of immunoradiometric assays that can distinguish POMC and proACTH from ACTH and MSH (Gibson et al. 1994), we have demonstrated that the ratio of $\mathrm{MSH}$ precursors to bioactive peptides is markedly altered in response to changes in energy requirement. This suggests that posttranslational processing of POMC may be regulated as a means of controlling energy homeostasis. These observations necessitate a detailed analysis of the expression and functional activity of POMC processing molecules within POMC neurons of various rat models of altered energy balance. In addition, it would be interesting to analyse POMC-derived peptide content in the csf of obese patients compared with controls.

\section{Relative Potency of POMC-derived Peptides at the MC4-R}

Although $\alpha \mathrm{MSH}$ is considered to be the most relevant peptide for activating the MC4R, other POMC-derived peptides, such as DA- $\alpha \mathrm{MSH}, \mathrm{ACTH}$ and $\beta \mathrm{MSH}$, have also been shown to activate cloned MC4R (Gantz et al. 1993, Mountjoy et al. 1994, 1999). Indeed both $\beta \mathrm{MSH}$ and DA- $\alpha \mathrm{MSH}$ are more potent in their effects in vitro than $\alpha \mathrm{MSH}$. These observations imply that numerous POMC-derived peptides may have functional relevance within the central melanocortin system. In view of our observations that POMC and proACTH are secreted within the hypothalamus and their concentrations are sensitive to changes in energy balance, it would be interesting to investigate whether these molecules also have the capacity to bind to and activate the MC4R. It would appear that hypothalamic POMC neurons do not produce and secrete a single MC4R agonist (such as $\alpha \mathrm{MSH}$ ), but probably secrete a complex 'soup' of MSH peptides and precursors that might activate MC4R with different affinities (Fig. 3).

The physiological relevance of $\mathrm{ACTH}, \beta \mathrm{MSH}$ and $\mathrm{DA}-\alpha \mathrm{MSH}$ is uncertain. Interestingly, i.c.v. injections of ACTH1-24 (Poggioli et al. 1986) and $\beta$ MSH (Abbott et al. 2000, Kask et al. 2000) into the brains of rats inhibit spontaneous feeding at least as potently as $\alpha \mathrm{MSH}$. Conversely, DA- $\alpha \mathrm{MSH}$ is 25 times less potent than aMSH in vivo (Abbott et al. 2000). This lack of in vivo potency may be accounted for by the relative instability of DA- $\alpha$ MSH compared with $\alpha \mathrm{MSH}$ (O'Donohue et al. 1981). Nevertheless, it has been noted that DA- $\alpha$ MSH is more predominant than $\alpha \mathrm{MSH}$ in rat hypothalamic extracts (Emerson \& Eipper 1986), so it could be that n-acetyltransferase activity in the hypothalamus plays a role in melanocortin signalling. The relative functional relevance of different POMC peptides will become clearer once peptide-specific, and tissue-specific, knockout mice are developed and characterised. Detailed analysis of the relative concentrations of peptides secreted from the hypothalamus will also shed further light on what peptides may be most functionally relevant at the MC4R (and, indeed the MC3R as well). Another aspect of melanocortin signalling that requires further analysis is the relationship between different POMC-derived peptides and the endogenous antagonist agouti-related peptide (AGRP). One study has indicated that agouti peptide (a homologue of AGRP) has a greater antagonistic effect on DA- $\alpha$ MSH than $\alpha \mathrm{MSH}$ at the MC4R (Mountjoy et al. 1999). The relationships between AGRP and DA- $\alpha M S H$, BMSH, ACTH, POMC or proACTH have not been investigated. It is possible that some ligands are less potently antagonised by AGRP than others, which may be physiologically relevant.

\section{Concluding Remarks}

Obesity is a major and costly health issue currently facing the developed world. As such there is great demand for anti-obesity therapies. The central melanocortin system is regarded as a key therapeutic target. Numerous genetic, cellular and physiological studies directly implicate POMC as a key element of melanocortin-mediated energy homeostasis. Therefore, with respect to the design of novel therapeutic strategies, it is of paramount importance that the mechanisms by which the POMC gene is regulated and post-translationally processed are understood. This article highlights issues regarding POMC biology that 


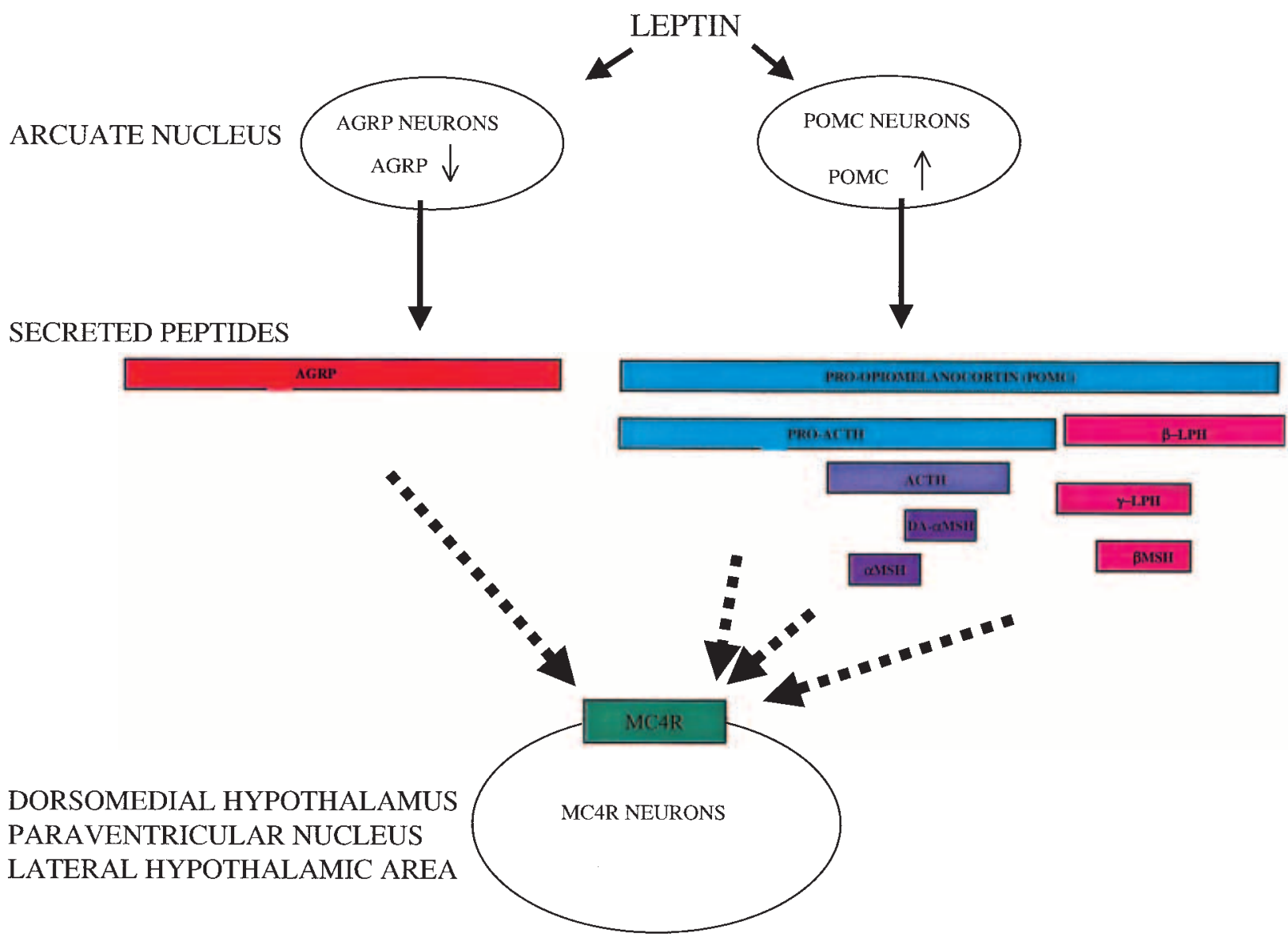

Figure 3 Interactions of POMC-derived peptides and AGRP at the MC4R. Leptin directly regulates POMC and AGRP expression in the arcuate nucleus. We have demonstrated that high levels of MSH precursor molecules, POMC, proACTH and ACTH, are secreted from POMC neurons, presumably along with $\alpha \mathrm{MSH}, \mathrm{DA}-\alpha \mathrm{MSH}, \gamma$-LPH and $\beta \mathrm{MSH}$ (see text for details). We presume that all of these peptides have the capacity to bind to, and activate MC4R. The relationship between each peptide and AGRP remains to be ascertained.

require further investigation. First, a better understanding of transcriptional regulation of POMC in the hypothalamus is required. Secondly, mechanisms by which POMC processing is regulated within the hypothalamus are not fully understood. Preliminary observations of prohormone convertase regulation in vivo and in vitro suggest leptin may mediate differential prohormone processing, depending on satiety status. Whether such a phenomena are physiologically relevant remains to be addressed. Thirdly, it is becoming increasingly clear that many POMC-derived peptides and precursors are secreted in the hypothalamus and can activate melanocortin receptors. It is not known, however, if different POMC-derived peptides act differently at melanocortin receptors in terms of the intracellular signalling pathways they evoke. Once such questions are addressed, it is possible that central POMC processing could be pharmacologically manipulated in obese individuals in order specifically to suppress appetite.

\section{References}

Abbott CR, Rossi M, Kim M-S, AlAhmed SH, Taylor GM, Ghatei MA, Smith DM \& Bloom SR 2000 Investigation of the melanocyte stimulating hormones on food intake. Lack of evidence to support a role for the melanocortin-3-receptor. Brain Research 869 203-210.

Allen RG, Peng B, Pellegrino MJ, Miller ED, Grandy DK, Lundblad JR, Washburn CL \& Pintar JE 2001 Altered processing of pro-orphanin FQ/Nociceptin and pro-opiomelanocortin-derived peptides in the brains of mice expressing defective prohormone convertase 2. Journal of Neurosciences 21 5864-5870.

Bagnol D, Lu X-Y, Kaelin CB, Day HEW, Ollmann M, Gantz I, Akil H, Barsh GS \& Watson SJ 1999 Anatomy of an endogenous antagonist: relationship between agouti-related protein and proopiomelanocortin in brain. Journal of Neurosciences 19 RC26.

Barsh GS, Farooqi IS \& O'Rahilly S 2000 Genetics of body-weight regulation. Nature 404 644-651.

Benjannet S, Rondeau N, Day R, Chretien M \& Seidah MG 1991 PC1 and PC2 are proprotein convertases capable of cleaving proopiomelanocortin at distinct pairs of basic residues. PNAS $\mathbf{8 8}$ 3564-3570. 
Benoit SC, Schwartz MW, Lachey JL, Hagan MM, Rushing PA, Blake KA, Yagaloff KA, Kurylko G, Franco L, Danhoo W \& Seeley RJ 2000 A novel selective melanocortin-4 receptor agonist reduces food intake in rats and mice without producing aversive consequences. Journal of Neurosciences 20 3442-3448.

Bergendahl M, Weiman JN, Clifton DK, Huhtaniemi I \& Steinar RA 1992 Short term starvation decreases POMC mRNA but does not alter $\mathrm{GnRH}$ mRNA in the brain of adult male rats. Neuroendocrinology 56 913-920.

Bergeron F, Leduc R \& Day R 2000 Subtilase-like pro-protein convertases: from molecular specificity to therapeutic applications. Journal of Molecular Endocrinology 24 1-22.

Berman Y, Mzhavia N, Polonskaia A \& Devi LA 2001 Impaired prohormone convertases in Cpe $e^{\text {fat }} / \mathrm{Cpe}^{\mathrm{fat}}$ mice. Journal of Biological Chemistry 276 1466-1473.

Bertagna X, Seidah N, Massias J-F, Lenne F, Luton J-P, Girard F \& Chretien M 1988 Microsequencing evidence for the maturation of human proopiomelanocortin into an 18 amino acid $\beta$-melanocyte stimulating hormone $[\mathrm{h} \beta \mathrm{MSH}(5-22)]$ in nonpituitary tissue. Peptides 10 83-87.

Bousquet C, Ray DW \& Melmed S 1997 A common pro-opiomelanocortin-binding element mediates leukemia inhibitory factor and corticotropin-releasing hormone transcriptional synergy. Journal of Biological Chemistry 272 10551-10557.

Bousquet C, Zatelli MC \& Melmed S 2000 Direct regulation of pituitary proopiomelanocortin by STAT3 provides a novel mechanism for immuno-neuroendocrine interfacing. Journal of Clinical Investigation 106 1417-1425.

Boutillier AL, Gaiddon C, Lorang D, Roberts JL \& Loeffler JP 1998 Transcriptional activation of the proopiomelanocortin gene by cyclic AMP-responsive element binding protein. Pituitary $133-43$.

Brady LS, Smith MA, Gold PW \& Herkenham M 1990 Altered expression of hypothalamic neuropeptide mRNAs in food-restricted and food-deprived rats. Neuroendocrinology 52 441-447.

Butler AA, Kesterson RA, Khong K, Cullen MJ, Pelleymounter MA, Dekoning J, Baetscher M \& Cone RD 2000 A unique metabolic syndrome causes obesity in the melanocortin-3 receptor-deficient mouse. Endocrinology 141 3518-3521.

Castro MG \& Morrison E 1997 Post-translational processing of proopiomelanocortin in the pituitary and in the brain. Critical Reviews in Neurobiology 11 35-57.

Chen AS, Marsh DJ, Trumbauer ME, Frazier EG, Guan X-M, Yu H, Rosenblum CI, Vongs A, Feng Y, Cao L et al. 2000 Inactivation of the mouse melanocortin-3 receptor results in increased fat mass and reduced lean body mass. Nature Genetics 26 97-102.

Chen W, Kelly MA, Opitz-Araya X, Thomas RE, Low MJ \& Cone RD 1997 Exocrine gland dysfunction in MC5-R-deficient mice: evidence for coordinated regulation of exocrine function by melanocortin peptides. Cell 91 789-798.

Cheung CC, Clifton DK \& Steiner RA 1997 Proopiomelanocortin neurons are direct targets for leptin in the hypothalamus. Endocrinology 138 4489-4492.

Chiesi M, Huppertz C \& Hofbauer KG 2001 Pharmacotherapy of obesity: targets and perspectives. Trends in Pharmacological Sciences 22 247-254.

Ciccotosto GD, Schiller MR, Eipper BE \& Mains RE 1999 Induction of integral membrane PAM expression in AtT-20 cells alters the storage and trafficking of POMC and PC1. Journal of Cell Biology 144 459-471.

Cintra A \& Bortolotti F 1992 Presence of strong glucocorticoid receptor immunoreactivity within hypothalamic and hypophyseal cells containing pro-opiomelanocortic peptides. Brain Research 577 127-133.

Clark AJ, McLoughlin L \& Grossman A 1993 Familial glucocorticoid deficiency associated with point mutation in the adrenocorticotropin receptor. Lancet 341 461-462.
Clement K, Vaisse C, Lahlou N, Cabrol S, Pelloux V, Cassuto D, Gourmelen M, Dina C, Chanbaz J, Lacorte JM et al. 1998 A mutation in the human leptin receptor gene causes obesity and pituitary dysfunction. Nature 392 398-401.

Comuzzie AG, Hixson JE, Almasy L, Mitchell BD, Mahaney MC, Dyer TD, Stern MP, MacCluer JW \& Blangero J 1997 A major quantitative trait locus determining serum leptin levels and fat mass is located on human chromosome 2. Nature Genetics $\mathbf{1 5}$ 273-276.

Cone RD 1999 The central melanocortin system and energy homeostasis. Trends in Endocrinology and Metabolism 10 211-216.

Cool DR, Normant E, Shen F, Chen H, Pannell L, Zhang Y \& Loh YP 1997 Carboxypeptidase E is a regulated secretory pathway sorting receptor: genetic obliteration leads to endocrine disorders in Cpe ${ }^{\text {fat }}$ mice. Cell 88 73-83.

Cowley MA, Smart JL, Rubinstein M, Cerdan MG, Diano S, Horvath TL, Cone RD \& Low MJ 2001 Leptin activates anorexigenic POMC neurons through a neural network in the arcuate nucleus. Nature $\mathbf{4 1 1}$ 480-484.

Diamond MI, Miner JN, Yoshinaga SK \& Yagamoto KR 1990 Transcription factor interactions: selectors of positive or negative regulation from a single DNA element. Science $\mathbf{2 4 9}$ $1266-1272$.

Dong W, Marcinkiewicz M, Vieau D, Chretien M, Seidah NG \& Day R 1995 Distinct mRNA expression of the highly homologous convertases PC5 and PACE4 in the rat brain and pituitary. Journal of Neurosciences 15 1778-1796.

Dong W, Seidel B, Marcinkiewicz M, Chretien M, Seidah NG \& Day R 1997 Cellular localization of the prohormone convertases in the hypothalamic paraventricular and supraoptic nuclei: selective regulation of $\mathrm{PC} 1$ in corticotrophin-releasing hormone parvocellular neurons mediated by glucocorticoids. Journal of Neurosciences $\mathbf{1 7}$ $563-575$

Drouin J, Sun YL, Chamberland M, Gauthier Y, De Lean A, Nemer M \& Schmidt TJ 1998 Novel glucocorticoid receptor complex with DNA element of the hormone-repressed POMC gene. EMBO Journal 12 145-156.

Emerson RB \& Eipper BA 1986 Characterization of proACTH/ endorphin derived peptides in rat hypothalamus. Journal of Neurosciences 6 837-849.

Fan W, Boston BA, Kesterson RA, Hruby VJ \& Cone RD 1997 Role of the melanocortinergic neurons in feeding and the agouti obesity syndrome. Nature 385 165-168.

Fehm HL, Smolnik R, Kern W, McGregor GP, Bickel U \& Born J 2001 The melanocortin melanocyte-stimulating hormone/ adrenocorticotropin(4-10) decreases body fat in humans. Journal of Clinical Endocrinology and Metabolism 86 1144-1148.

Fricker LD, McKinzie AA, Sun J, Curran E, Qian Y, Yan L, Patterson SD, Courchesne PL, Richards B, Levin N et al. 2000 Identification and characterisation of proSAAS, a granin-like neuroendocrine peptide precursor that inhibits prohormone processing. Journal of Neurosciences 20 639-648.

Gantz I, Miwa H, Konda Y, Shimoto Y, Tashiro T, Watson SJ, DelValle J \& Yamada T 1993 Molecular cloning, expression, and gene localization of a fourth melanocortin receptor. Journal of Biological Chemistry 268 15174-15179.

Gibson S, Crosby SR, Stewart MF, Jennings AM, McCall E \& White A 1994 Differential release of proopiomelanocortin-derived peptides from the human pituitary: evidence from a panel of two-site immunoradiometric assays. Journal of Clinical Endocrinology and Metabolism 78 835-841.

Good DJ 2000 How tight are your genes? Hormones and Behaviour 37 284-298.

Hagan MM, Rushing PA, Schwartz MW, Yagaloff KA, Burn P, Woods SC \& Seeley RJ 1999 Role of the CNS melanocortin system in the response to overfeeding. Journal of Neurosciences 19 $2362-2367$. 
Hager J, Dina C, Francke S, Dubois S, Houari M, Vatin V, Vaillant E, Lorentz N, Basdevant A, Clement K et al. 1998 A genome-wide scan for human obesity genes reveals a major susceptibility locus on chromosome 10. Nature Genetics 20 304-308.

Hakansson ML \& Meister B 1998 Transcription factor STAT3 in leptin target neurons of the rat hypothalamus. Neuroendocrinology 68 420-427.

Harrold JA, Williams G \& Widdowson PS 1999 Changes in hypothalamic agouti-related protein (AGRP), but not $\alpha$-MSH or pro-opiomelanocortin concentrations in dietary-obese and food-restricted rats. Biochemical and Biophysical Research Communications 258 574-577.

Hinney A, Becker I, Heibult O, Nottebom K, Schmidt A, Ziegler A, Mayer H, Siegfried W, Blum WF, Remschmidt H \& Hebebrand J 1998 Systematic mutation screening of the pro-opiomelanocortin gene: identification of several genetic variants including three different insertions, one nonsense and two missense point mutations in probands of different weight extremes. Journal of Clinical Endocrinology and Metabolism 83 3737-3741.

Hixson JE, Almasy L, Cole S, Birnbaum S, Mitchell BD, Mahaney MC, Stern MP, MacCluer JW, Blangero J \& Comuzzie AG 1999 Normal variation in leptin levels is associated with polymorphisms in the proopiomelanocortin gene, POMC. Journal of Clinical Endocrinology and Metabolism 84 3187-3191.

Huszar D, Lynch CA, Fairchild-Huntress V, Dunmore JH, Fang Q, Berkemeier LR, Gu W, Kesterson RA, Boston BA, Cone RD et al. 1997 Targeted disruption of the melanocortin-4 receptor results in obesity in mice. Cell 88 131-141.

Jackson RS, Creemers JWM, Ohagi S, Raffin-Sanson M-L, Sanders L, Montague CT, Hutton JC \& O'Rahilly S 1997 Obesity and impaired prohormone processing associated with mutations in the human prohormone convertase 1 gene. Nature Genetics 16 303-306.

Jackson RS, O’Rahilly SO, Brain C \& Nussey SS 1999 Proopiomelanocortin products and human early-onset obesity Journal of Clinical Endocrinology and Metabolism 84 819-820.

Jegou S, Boutelet I \& Vaudry H 2000 Melanocortin-3 receptor mRNA expression in pro-opiomelanocortin neurones of the rat arcuate nucleus. Journal of Neuroendocrinology 12 501-505.

Kask M, Rago L, Wikberg JES \& Schioth HB 2000 Differential effects of melanocortin peptides on ingestive behaviour in rats: evidence against the involvement of MC3 receptor in the regulation of food intake. Neuroscience Letters 283 1-4.

Kim E-M, Grace MK, Welch CC, Billington CJ \& Levine AS 1999 STZ-induced diabetes decreases and insulin normalizes POMC mRNA in arcuate nucleus and pituitary in rats. American Journal of Physics 276 R1320-R1326.

Kim E-M, O’Hare E, Grace MK, Welch CC, Billington CJ \& Levine AS 2000 ARC POMC mRNA and PVN $\alpha-M S H$ are lower in obese relative to lean Zucker rats. Brain Research 862 11-16.

Korner J, Chua SC, Williams JA, Leibel RL \& Wardlaw SL 1999 Regulation of hypothalamic proopiomelanocortin by leptin in lean and obese rats. Neuroendocrinology 377-383.

Krude H \& Gruters A 2000 Implications of proopiomelanocortin (POMC) mutations in humans: the POMC deficiency syndrome. Trends in Endocrinology and Metababolism 11 15-22.

Krude H, Biebermann H, Luck W, Horn R, Brabant G \& Gruters A 1998 Severe early-onset obesity, adrenal insufficiency, and red hair pigmentation caused by POMC mutations in humans. Nature Genetics 20 111-112.

Lander E \& Kruglyak L 1995 Genetic dissection of complex traits: guidelines for interpreting and reporting linkage results. Nature Genetics 11 241-247.

Li Q-L, Jansen E, Brent GA, Naqvi S, Wilber JF \& Friedman TC 2000 Interactions between the prohormone convertase 2 promoter and the thyroid hormone receptor. Endocrinology 141 3256-3266.

Li Q-L, Jansen E, Brent GA \& Friedman TC 2001 Regulation of prohormone convertase 1 (PC1) by thyroid hormone. American Journal of Physiology Endocrinology and Metabolism 280 E160-E170.
Lindberg I, Van den Hurk WH, Bui C \& Batie CJ 1995 Enzymatic characterization of immunopurified prohormone convertase 2 . Potent inhibition by a 7B2 peptide fragment. Biochemistry 34 5486-5493.

Liotta AS, Loudes C, McKelvy JF \& Krieger DT 1980 Biosynthesis of precursor corticotropin/endorphin-, corticotropin-, $\alpha$-melanotropin-, $\beta$-lipotropin-, and $\beta$-endorphin-like material by cultured neonatal rat hypothalamic neurons. PNAS 77 1880-1884.

Loh YP, Parish DC \& Tuteja R 1985 Purification and characterization of a paired basic residue-specific proopiomelanocortin converting enzyme from bovine pituitary intermediate lobe secretory vesicles. Journal of Biological Chemistry 260 7194-7200.

Mercer JG, Hoggard N, Williams MN, Lawrence CB, Hannah LT, Morgan PJ \& Trayhurn P 1996 Coexpression of leptin receptor and preproneuropeptide $\mathrm{Y}$ mRNA in arcuate nucleus of mouse hypothalamus. Journal of Neuroendocrinology 8 733-735.

Mizuno TM \& Mobbs CV 1999 Hypothalamic agouti-related protein messenger ribonucleic acid is inhibited by leptin and stimulated by fasting. Endocrinology 140 814-817.

Mizuno TM, Kleopoulos SP, Bergen HT, Roberts JL, Priest CA \& Mobbs CV 1998 Hypothalamic pro-opiomelanocortin mRNA is reduced by fasting and in ob/ob and $\mathrm{db} / \mathrm{db}$ mice, but is stimulated by leptin. Diabetes 47 294-297.

Mizuno TM, Makimura H, Silverstein J, Roberts JL, Lopingco T \& Mobbs CV 1999 Fasting regulates hypothalamic neuropeptide Y, agouti related peptide, and proopiomelanocortin in diabetic mice independent of changes in leptin or insulin. Endocrinology 1999 4551-4557.

Montague CT, Farooqi IS, Whitehead JP, Soos MA, Rau H, Wareham NJ, Sewter CP, Digby JE, Mohammed SN, Hurst JA et al. 1997 Congenital leptin deficiency is associated with severe early-onset obesity in humans. Nature 387 903-908.

Mountjoy KG, Mortrud MT, Low MJ, Simerly RB \& Cone RD 1994 Localisation of the melanocortin-4 receptor (MC4-R) in neuroendocrine and autonomic control circuits in the brain. Molecular Endocrinology 8 1298-1308.

Mountjoy KG, Willard DH \& Wilkison WO 1999 Agouti antagonism of melanocortin-4 receptor: greater effect with desacetyl- $\alpha-$ melanocyte-stimulating hormone (MSH) than with $\alpha$-MSH. Endocrinology 1999 2167-2172.

Naggert JK, Fricker LD, Varlamov O, Nishini PM, Rouille Y, Steiner DF, Carroll RJ, Paigen BJ \& Leiter EH 1995 Hyperproinsulinaemia in obese fat/fat mice associated with a carboxypeptidase E mutation which reduces enzyme activity. Nature Genetics 10 135-142.

Nillni EA, Flier JS \& Bjorbaek C 2001 Leptin stimulates the expression and biosynthesis of prohormone convertases 1 and 2 (PC1 and PC2) in hypothalamic neurons. Keystone Symposia. Obesity and Regulation of Energy Homeostasis Feb 24-March 1. Taos, New Mexico. Abstract 112

O'Donohue TL, Handelmann GE, Chaconas RL, Miller DM \& Jacobwitz DM 1981 Evidence that N-acetylation regulates the behavioural activity of alpha-MSH in the rat and human central nervous system. Peptides 2 333-344.

Ollmann MM, Wilson BD, Yang Y-K, Kerns JA, Chen Y, Gantz I \& Barsh GS 1997 Antagonism of central melanocortin receptors in vitro and in vivo by agouti-related protein. Science 278 135-138.

O'Rahilly S, Gray H, Humphreys PJ, Krook A, Polonsky MD, White A, Gibson S, Taylor K \& Carr C 1995 Brief report: impaired processing of prohormones associated with abnormalities of glucose homeostasis and adrenal function. New England Journal of Medicine 333 1386-1390.

Poggioli R, Vergoni AV \& Bertolini A 1986 ACTH(1-24) and $\alpha-\mathrm{MSH}$ antagonize feeding behaviour stimulated by kappa opiate agonists. Peptides 7 843-848.

Pritchard L, Birtles S, McLoughlin J, Turnbull AV \& White A 2001 Central POMC processing in fed/fasted Wistar and lean/obese Zucker rats. British Neuroscience Association Abstracts 1668. 
Qian Y, Devi LA, Mzhavia N, Munzer S, Seidah NG \& Ficker LD 2000 The C-terminal region of proSAAS is a potent inhibitor of prohormone convertase 1. Journal of Biological Chemistry 275 23596-23601.

Renz M, Tomlinson E, Hultgren B, Levin N, Gu Q, Shimkets RA, Lewin DA \& Stewart TA 2000 Quantitative expression analysis of genes regulated by both obesity and leptin rveals a regulatory loop between leptin and pituitary-derived ACTH. Journal of Biological Chemistry 275 10429-10436.

Robbins LS, Nadeau JH, Johnson KR, Kelly MA, Roselli-Rehfuss L, Back E, Mountjoy KG \& Cone RD 1993 Pigmentation phenotypes of variant extension locus alleles result from point mutations that alter MSH receptor function. Cell 72 827-834.

Roselli-Rehfuss L, Mountjoy KG, Robbins LS, Mortrud MT, Low MJ, Tatro JB, Entwistle ML, Simerly RB \& Cone RJ 1993 Identification of a receptor for $\gamma$ melanotropin and other proopiomelanocortin peptides in the hypothalamus and limbic system. PNAS $908856-8890$.

Rotimi CN, Comuzzie AG, Lowe WL, Luke A, Blangero J \& Cooper RS 1999 The quantitative trait locus on chromosome 2 for serum leptin levels is confirmed in African-Americans. Diabetes 48 643-644.

Rouille Y, Duguay SJ, Lund K, Furuta M, Gong Q, Lipkind G, Oliva AA, Chan SJ \& Steiner DF 1995 Proteolytic processing mechanisms in the biosynthesis of neuroendocrine peptides: the subtilisin-like proprotein convertases. Frontiers in Neuroendocrinology 16 322-361.

Rubinstein M, Mortrud M, Liu B \& Low MJ 1993 Rat and mouse proopiomelanocortin gene sequences target tissues specific expression to the pituitary gland but not to the hypothalamus of transgenic mice. Neuroendocrinology 58 373-380.

Schwartz MW, Seeley RJ, Woods SC, Weigle DS, Campfield LA, Burn P \& Baskin DG 1997 Leptin increases hypothalamic pro-opiomelanocortin mRNA expression in the rostral arcuate nucleus. Diabetes 46 2119-2123.

Schwartz MW, Woods SC, Porte D, Seeley RJ \& Baskin DG 2000 Central nervous system control of food intake. Nature 404 661-671.

Spiegelman BM \& Flier JS 2001 Obesity and the regulation of energy balance. Cell 104 531-543.

Strobel A, Issad T, Camoin L, Ozata M \& Strosberg AD 1998 A leptin missense mutation is associated with hypogonadism and morbid obesity. Nature Genetics 18 213-215.
Thomas L, Leduc R, Thorne BA, Smeekens SP, Steiner DF \& Thomas G 1991 Kex-2 like endoproteases PC2 and PC3 accurately cleave a model prohormone in mammalian cells: evidence for a common core of neuroendocrine processing enzymes. PNAS $\mathbf{8 8}$ $5297-5301$.

Tsigos C, Crosby SR, Gibson S, Young RJ \& White A 1993 Proopiomelanocortin is the predominant adrenocorticotropin-related peptide in human cerebrospinal fluid. Journal of Clinical Endocrinology and Metabolism 76 620-624.

Vaisse C, Clement K, Guy-Grand B \& Froguel P 1998 A frameshift mutation in human MC4R is associated with a dominant form of obesity. Nature Genetics 20 113-114.

Wardlaw SL, McCarthy KC \& Conwell IR 1998 Glucocorticoid regulation of hypothalamic proopiomelanocortin. Neuroendocrinology $6751-57$.

White A \& Gibson S 1998 ACTH precursors: biological significance and clinical relevance. Clinical Endocrinology 48 251-255.

Yaswen L, Diehl N, Brennan MB \& Hochgeschwender U 1999 Obesity in the mouse model of pro-opiomelanocortin deficiency responds to peripheral melanocortin. Nature Medicine 5 1066-1070.

Yeo GS, Farooqi IS, Aminian S, Halsall DJ, Stanhope RJ \& O'Rahilly S 1998 A frameshift mutation in MC4R associated with dominantly inherited human obesity. Nature Genetics 20 111-112.

Yeo GSH, Farooqi IS, Challis BG, Jackson RS \& O'Rahilly S 2000 The role of melanocortin signalling in the control of body weight: evidence from human and murine genetic models. Quarterly Journal of Medicine 93 7-14.

Young JI, Otero V, Cerdan MG, Falzone TL, Chan EC, Low MJ \& Rubinstein M 1998 Authentic cell-specific and developmentally regulated expression of pro-opiomelanocortin genomic fragments in hypothalamic and hindbrain neurons of transgenic mice. Journal of Neurosciences 18 6631-6640.

Zhou A \& Mains RE 1994 Endoproteolytic processing of proopiomelanocortin and prohormone convertases 1 and 2 in neuroendocrine cells overexpressing prohormone convertases 1 or 2 . Journal of Biological Chemistry 269 17440-17447.

Received 24 October 2001

Accepted 19 November 2001 